https://doi.org/10.5817/NR2019-1-12

\section{II. brněnské literárněvědné kolokvium}

Ve dnech 9. a 10. ř́jna 2018 se na půdě Filozofické fakulty Masarykovy univerzity uskutečnilo mezinárodní Brněnské literárněvědné kolokvium doktorandů, realizované s podporou projektu Mezinárodní doktorská škola. V pořadí již druhý ročník setkání doktorandů a jejich školitelů z Polska, Litvy, Ukrajiny, České a Slovenské republiky byl věnován osobnosti a tvorbě ruského klasika F. M. Dostojevského (1821-1881). Tematické zaměření kolokvia bylo vymezeno aktuální problematikou studia osobnosti a tvorby Dostojevského, zahrnovalo význam a místo spisovatele v kontextu slovanských literatur, jako i současné trendy výzkumu jeho děl.

Úvodní slovo pronesli organizátor kolokvia a vedoucí Ústavu slavistiky prof. PhDr. Ivo Pospíšil, DrSc., a proděkan pro zahraniční vztahy Filozofické fakulty Masarykovy univerzity doc. PhDr. Tomáš Pospíšil, Ph.D. Jednání svým př́spěvkem otevřela ukrajinská vědkyně Olha Červynska (Ольга Червинська), která v románu Výrostek odhalila klíčové slovo, z jehož symboliky vychází interpretace celého románu. České prostředí reprezentovaly tři př́spěvky. Radka Hříbková se věnovala symbolice mimiky a dětských gest v Dostojevského tvorbě. Př́spěvek mapující činnost Společnosti Dostojevského v letech 2004-2018 přednesla Miluše
Bubeníková, shrnula v něm dosavadní výsledky, důležité milníky a naznačila další perspektivy činnosti spolku. Organizátor kolokvia Ivo Pospíšil poukázal na úskalí, která přináší současný výzkum Dostojevského tvorby. Př́spěvek slovenské rusistky Natálie Muránské přibližil recepci osobnosti a tvorby Dostojevského ve slovenském prostředí, zejména pohled na spisovatele očima dostojevskologa Andreje Červeňáka (1932-2012).

Doktorandi představili témata vycházející z jejich výzkumů. Ingrida Kiseliutè $\mathrm{z}$ Litvy vystoupila se zajímavým příspěvkem o perspektivách výzkumu Dostojevského tvorby na základě hodnoty peněz. Doktorandka z Polska Paulina Sikora-Krizhevska zkoumala na př́kladu adaptace novely Strýčkưv sen možnosti divadelního zpracování Dostojevského děl. Filmové zpracování Dostojevského biografie zhodnotila Natalija Valerianovna Nikorjak (Наталия Валериановна Никоряк) z Ukrajiny. Její kolega Roman Anatoljevič Dzyk (Роман Анатольевич Дзык) se věnoval současným trendům $\mathrm{v}$ ukrajinské dostojevskologii. Lenka Paučová srovnala měnící se pohled na osobnost F. M. Dostojevského a dílo Deník spisovatele $\mathrm{v}$ encyklopedických publikacích vydaných $\mathrm{v}$ Rusku v různých obdobích.

Jednání pokračovalo druhým konferenčním dnem; shrnutím přednesených příspěvků a nastolením dalších souvisejících problémů, jakými jsou například různé pohledy na místo Dostojevského v obsahové náplni univerzitních kurzů zaměřených na ruskou 
a světovou literaturu. Kolokvium přispělo $\mathrm{k}$ prohloubení spolupráce mezi doktorandy a akademickými pracovníky zabývajícími se osobností a tvorbou F. M. Dostojevského.

Lenka Paučová

https://doi.org/10.5817/NR2019-1-13

\section{Dialog kultur oslavil jubileum}

Jubilejní desátý ročník oslavila mezinárodní vědecká konference Dialog kultur, která se uskutečnila ve dnech 15 . a 16. ledna 2019 na Pedagogické fakultě Univerzity Hradec Králové. O organizaci se již tradičně postarala Katedra ruského jazyka a literatury ve spolupráci se Slavistickou společností Franka Wollmana a s Českou asociací rusistů.

Konferenci zahájila prorektorka UHK pro tvůrčí činnost Mgr. Leona Stašová, Ph.D., podporu ze strany PdF UHK vyjádřila proděkanka pro internacionalizaci a praxe Mgr. Daniela Vrabcová, Ph.D. Za pořadatele pomluvila vedoucí KRJL PdF UHK Mgr. Jana Kostincová, Ph.D., na niž navázal předseda Slavistické společnosti Franka Wollmana prof. PhDr. Ivo Pospíšil, DrSc. Úvodní část konference zakončil předseda České asociace rusistů Mgr. Jiř́ Klapka, který zpestřil program hudební vložkou a představením vzácných textů z nových hudebních sborníků.

Na letošním Dialogu kultur se zase jednalo ve třech sekcích - v literárněvědné, lingvistické a lingvodidaktické. Literární vědci a vědkyně se $\mathrm{v}$ tomto roce zaměřili na problematiku slovanských literatur a podob performance a řešili množství aktuálních otázek jako např́ílad téma paměti v ruské a české literatuře, tvorba J.S. Machara v souvislosti s ruskou literaturou, prredstavovali performanci $\mathrm{v}$ kontextu divadla a konceptuální literatury aj.

V oblasti lingvistiky se rokovalo o cizojazyčných vlivech na slovanské jazyky na různých úrovních jazykového systému. Mimo jiné se řešily otázky silných a slabých stránek korpusu Intercorp a možností jeho použití $v$ prèekladatelské práci, precedentní fenomény z oblasti sportu, řešila se translatologická problematika (např́klad práce s terminologií v oblasti sociální sféry), vzpomínalo se na znakové osobnosti v lingvistice a stále aktuální diskuze o ruském jazyce na začátku 21. století aj.

Současné téma bylo rozvíjeno i v lingvodidaktické sekci, ve které se zabývalo moderními tendencemi $\mathrm{v}$ didaktice ruského jazyka. Zde účastnici diskutovali na témata používání vokální tvorby ve výuce fonetiky, lexiky a gramatiky, efektivního využití videomateriálu při výuce praktického jazyka, zpracování nových učebních materiálů, uměleckého textu jako výukového materiálu na hodinách ruského jazyka.

$\mathrm{Na}$ Dialogu kultur se svými príspěvky vystoupilo 50 odborníků a odbornic v oblastech lingvistiky, literární vědy a didaktiky, přičemž několik dalších kolegů a kolegyň přicestovalo i ze zahraničí bez 